\title{
PENGARUH KADAR AIR AWAL KAYU JATI DAN SUHU CURING PEREKAT PADA KEKUATAN GESER SAMBUNGAN KAYU JATI (TECTONA GRANDIS) SECARA PEREKATAN
}

\author{
Sugiman, Abdul Hayyi Nu'man, Emmy Dyah Sulistyowati \\ Jurusan Teknik Mesin Fakultas Teknik Universitas Mataram \\ Jln. Majapahit No.62 Mataram Nusa Tenggara Barat Kode Pos: 83125 \\ Telp. (0370) 636087; 636126; ext 128 Fax (0370) 636087 \\ *Email: s.sugiman@tm.ftunram.ac.id
}

\begin{abstract}
Adhesively wood-wood bonded joint has been widely used in structural applications, however because wood is a hygroscopic material that absorbed water from environment, hence the absorbed water affects the joints performance. The objective of the paper is to investigate water absorbtion and desorbtion behaviour and the combined effect of absorbed water into the wood before being bonded and adhesive curing temperature on the shear strength of teak wood joints. The initial water content in the wood was $0 \%, 37 \%$, and $54 \%$, while the curing temperature was a room temperature for 24 hours, $50^{\circ} \mathrm{C}$ for 6 hours, and $100^{\circ} \mathrm{C}$ for 3 hours. The water absorbtion behaviour of teak wood deviate from the Fick's law, however the desorbtion tends to follow the Fick's law. Moreover the rate of absorbtion is higher than the rate of desorbtion. At the same curing temperature, the increase of water content decreases the shear strength of the joints; however the decrease was compensated by increasing the curing temperature. Curing at a high temperature $\left(100^{\circ} \mathrm{C}\right)$ improves the joints strength in all moisture content studied and the failure of the joints occurs at the wood.
\end{abstract}

Keywords: wood, adhesive, water, curing temperature, shear strength.

\section{PENDAHULUAN}

Kayu jati telah lama dipakai untuk komponen struktural karena sifat mekanik dan daya tahan kayu jati yang sangat baik dibanding jenis kayu yang lain. Sambungan tidak dapat terhindarkan dalam penggunaan kayu jati sebagai komponen struktural atau non struktural di industri transportasi seperti bodi kapal laut dan interior kereta api. Sambungan dengan perekat telah lama diaplikasikan dalam struktural kayu, namun sifat kayu adalah sangat higroskopis, mampu menyerap air dalam jumlah banyak hingga $200 \%$ dan menyebabkan swelling kayu [1]. Air yang terkandung dalam kayu berpengaruh terhadap kekuatan sambungan perekat dan daya tahannya melalui kayu itu sendiri, perekat dan interface kayu/perekat [2].

Perekat epoxy mampu merekatkan banyak material termasuk kayu, namun pemakaian pada kayu masih memerlukan penelitian yang mendalam terutama dalam hal durabilitasnya karena terekspos oleh lingkungan, seperti kelembaban [3]. Air berpengaruh buruk pada kekuatan sambungan kayu secara perekatan. Pada sambungan kayu-FRP dengan perekat epoxy, pengujian pada kondisi basah mampu menurunkan kekuatan geser sambungan $43 \%$ dibanding kekuatan pada pengujian kering [4]. Di samping pengaruh air pada kekuatan sambungan, pengaruh lain yang sangat berperan ketika kayu menyerap air adalah swelling dan penyusutan terutama pada arah tegak lurus arah butir longitudinal kayu [5].

Suhu curing sangat berperan terhadap proses curing perekat dan juga kekuatan sambungan [6] melaporkan bahwa penggunaan suhu curing yang tinggi $\left(120^{\circ} \mathrm{C}\right.$ selama 3 jam) memberikan kekuatan geser yang optimal pada sambungan perekat baja karbon rendah dengan perekat steel-filled epoxy. Suhu curing tinggi $\left(100{ }^{\circ} \mathrm{C}\right)$ juga memberikan kekuatan yang baik pada laju perambatan retak pada sambungan perekat komposit fibreglass/polyester tak jenuh dengan perekat epoxy, walaupun terdapat kadar air dalam komposit sekitar 2,8\% [7]. Komposit mempunyai pori-pori permukaan yang kecil dan menyerap air yang lebih sedikit dibanding kayu. Swelling dan susutan komposit juga kecil dibanding kayu, sehingga efek keduanya tidak sebesar pada kayu.

Dalam aplikasi, kadang kayu tidak dapat mencapai kering sempurna dan harus disambung walau kayu masih mengandung air. Sambungan dengan perekat memerlukan pengeringan dan pengeringan perekat lebih baik ketika digunakan suhu curing yang 
tinggi. Sehingga penggunaan suhu curing perekat tinggi dengan kayu masih mengandung air memungkinkan untuk dilakukan. Tujuan dari paper ini adalah untuk mengetahui pengaruh kadar air awal pada kayu jati dan suhu curing perekat terhadap kekuatan geser sambungan perekat kayu jati dengan menggunakan perekat epoxy. Sifat penyerapan air (absorbsi) dan pengeluaran air (desorbsi) kayu dipelajari, demikian juga swelling dan susutan kayu karena air.

\section{METODE PENELITIAN}

\section{Absorpsi dan desorpsi air pada kayu}

Sebelum proses absorpsi air, kayu jati berbentuk plat dengan dimensi panjang $5 \mathrm{~cm}$, lebar $5 \mathrm{~cm}$ dan tebal spesimen kurang lebih 3 $\mathrm{mm}$ dikeringkan dengan menggunakan oven pada suhu $100{ }^{\circ} \mathrm{C}$ sampai kering. Untuk mengetahui bahwa kayu telah kering, setiap satu jam kayu ditimbang dengan menggunakan timbangan digital dan ketebalannya diukur dengan menggunakan micrometer sampai berat dari kayu konstan.

\section{Proses absorpsi air pada kayu}

Setelah kayu jati benar-benar kering, kayu direndam di dalam air pada suhu kamar. Setiap 5 menit kayu ditimbang dengan menggunakan timbangan digital dan ketebalannya diukur dengan menggunakan micrometer. Proses tersebut dilakukan secara periodik sampai berat kayu konstan atau bertambah secara tidak signifikan.

\section{Proses desorbsi air pada kayu}

Setelah kayu menyerap air dan beratnya tidak bertambah, maka kayu kemudian dikeringkan pada suhu kamar. Setiap 5 menit kayu ditimbang dengan menggunakan timbangan digital, demikian juga penyusutan ketebalan kayu. Langkah ini dilakukan sampai berat dari kayu konstan. proses absorbsi dan desorbsi kemudian diplot ke dalam kurva kadar air penyerapan vs akar waktu seperti Gambar 1.

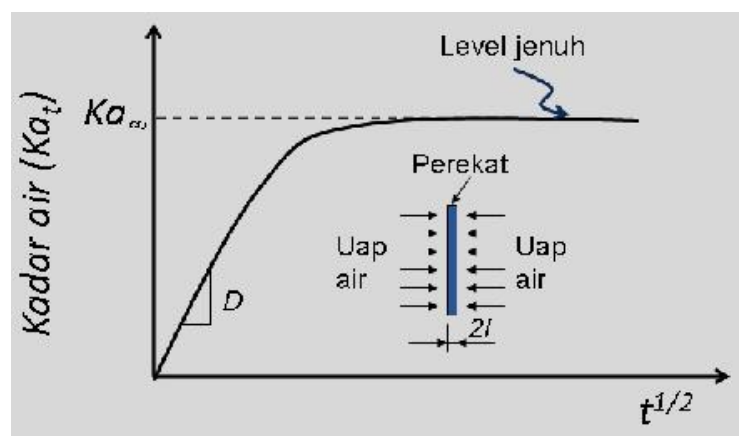

Gambar 1. Kurva kadar air absorbsi $\left(K a_{t}\right)$ vs akar waktu $(t)$ sesuai hukum Fick.
Berdasar pada hukum Fick kedua, kurva kadar air penyerapan $\left(K a_{t}\right)$ dengan waktu dapat dirumuskan seperti Pers. (1) [8].

$$
\frac{K a_{t}}{K a_{\infty}}=1-\frac{8}{\pi^{2}} \sum_{n=0}^{\infty} \frac{1}{(2 n+1)^{2}} \exp \left[\frac{-(2 n+1)^{2} \pi^{2} D t}{4 l^{2}}\right]
$$

Sedangkan konstanta difusi $(D)$ dihitung dari daerah linier kira-kira sampai $0,6 \mathrm{Ka}_{t} / \mathrm{Ka}_{\infty}$ seperti Pers. (2) [8].

$$
\frac{K a_{t}}{K a_{\infty}}=\frac{4}{l} \sqrt{\frac{D t}{\pi}}
$$

dengan $K \mathrm{a}_{t}$ adalah kadar air penyerapan sebagai fungsi waktu, $K a_{\infty}$ adalah kadar air penyerapan saat kesetimbangan.

\section{Pengujian Kekuatan Tarik Kayu}

Disamping sambungan kayu, kayu jati juga direndam dalam air pada suhu kamar dan kemudian diuji tarik untuk mengetahui kekuatan tarik kayu pada kadar air penyerapan yang berbeda-beda. Spesimen uji tarik kayu seperti Gambar 2a. Sebelum direndam, kayu dikeringkan menggunakan oven dengan suhu $100{ }^{\circ} \mathrm{C}$ sampai kering. Untuk uji tarik kayu dengan kelembaban $0 \%$, kayu langsung diuji setelah kering atau bila pengujian mengalami penundaan, kayu dimasukkan ke dalam plastik kedap udara agar tidak menyerap uap air dari udara selama penyimpanan. Sedangkan untuk uji tarik kayu dengan kadar air $37 \%$ dan $54 \%$, kayu direndam dalam air pada suhu kamar sampai mencapai kadar air $37 \%$ dan $54 \%$. Pemilihan kadar air penyerapan tersebut untuk mewakili kayu kering (kadar air $0 \%$ ), kadar air tengah $(37 \%)$ dan kadar air saat penyerapan air cenderung konstan (kadar air 54\%). Kadar air dan lama penyerapan tersebut ditentukan dari kurva hasil penyerapan air vs akar waktu pada kayu (lihat Gambar 4). Pengujian tarik dilakukan dengan mesin uji tarik universal Control kapasitas $2000 \mathrm{kN}$.

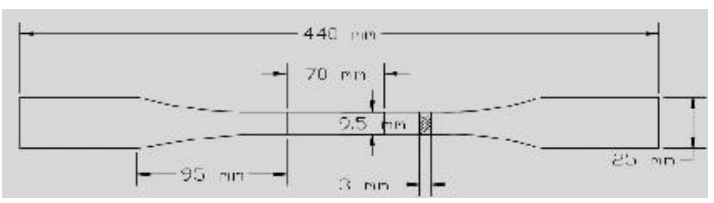

(a)

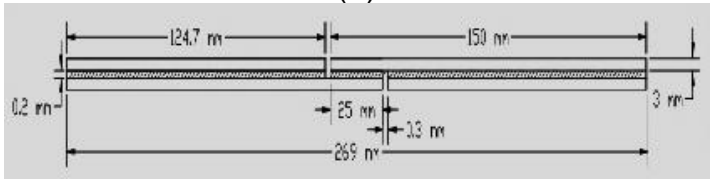

(b)

Gambar 2. (a) Spesimen uji tarik kayu SNI 03-3399-1994[9] (b) Spesimen sambungan Ozcan[10]. Lebar spesimen sambungan $50 \mathrm{~mm}$. 


\section{Spesimen dan pengujian kekuatan geser sambungan}

Sebelum proses pembuatan sambungan, kayu yang akan disambung direndam dalam air untuk mendapatkan kadar air yang telah ditentukan (kelembaban awal); $37 \%$ dan $54 \%$. Setelah kayu mencapai kadar air yang ditentukan tersebut, kayu langsung disambung dengan menggunakan perekat epoxy. Untuk kadar air 0\%, kayu langsung disambung setelah kayu kering seperti pada pengujian kekuatan tarik. Perekat yang digunakan menggunakan epoxy dengan perbandingan volume resin : hardener adalah 1: 1. Perekat dioleskan secara merata pada kayu dan untuk menjaga agar ketebalan seragam pada sambungan disisipkan kawat tembaga dengan diameter $0,2 \mathrm{~mm}$, sehingga dihasilkan ketebalan perekat sama seperti diameter kawat. Setelah selesai direkatkan kemudian sambungan diclam dengan penjepit kertas dan kemudian dikeringkan. Suhu pengeringan yang digunakan adalah pada suhu kamar (SR) selama 24 jam, $50{ }^{\circ} \mathrm{C}$ selama 6 jam (kode 50(6)) dan $100{ }^{\circ} \mathrm{C}$ selama 3 jam (kode 100(6)). Gambar spesimen perekatan dapat dilihat seperti Gambar 2b.

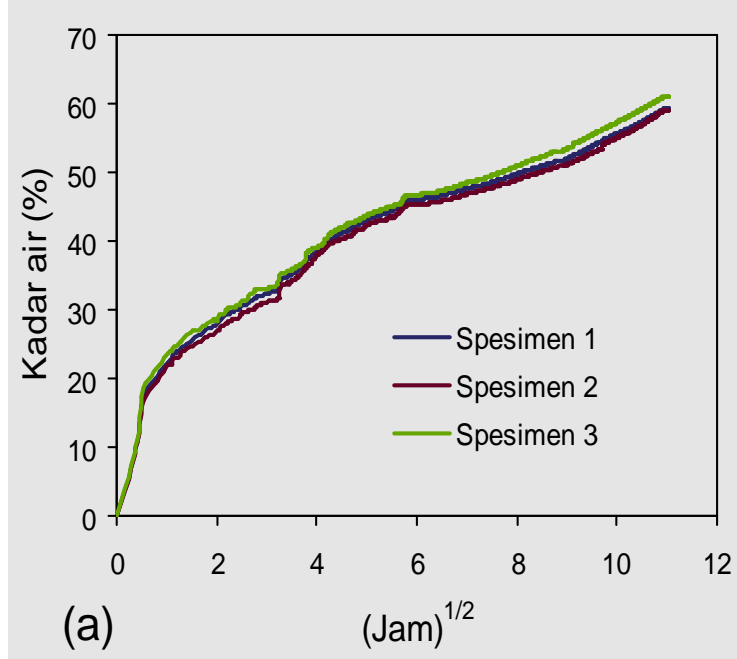

\section{HASIL DAN PEMBAHASAN}

\section{Absorbsi dan desorbsi kayu}

Setelah dilakukan pengovenan dapat disajikan data berat spesimen dengan waktu pengovenan seperti pada Gambar 3. Dari Gambar 3 dapat dilihat bahwa berat ketiga spesimen menurun tajam pada 1 jam pertama, kemudian setelah itu penurunan menjadi lebih landai. Berat kayu konstan setelah dilakukan pengovenan selama 7 jam. Sehingga, dapat disimpulkan berat kering tanur kayu diperoleh dengan lama pengovenan selama 7 jam dengan menggunakan suhu pengeringan $100{ }^{\circ} \mathrm{C}$.

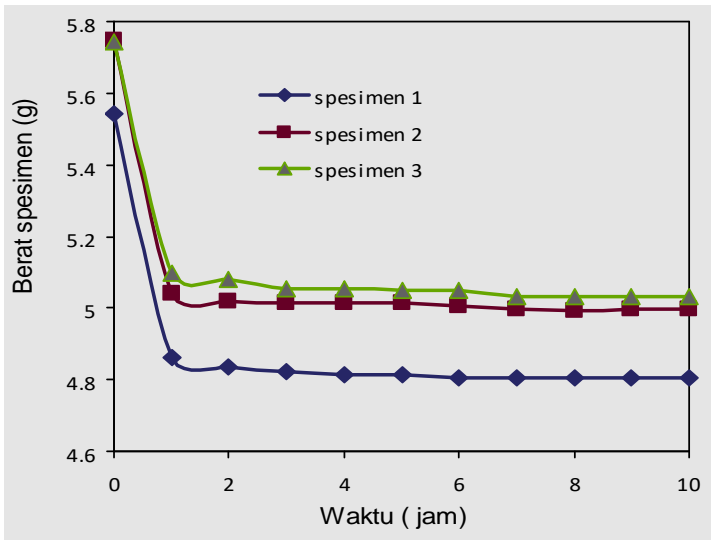

Gambar 3. Grafik hubungan antara berat kayu dengan dengan waktu pengovenan.

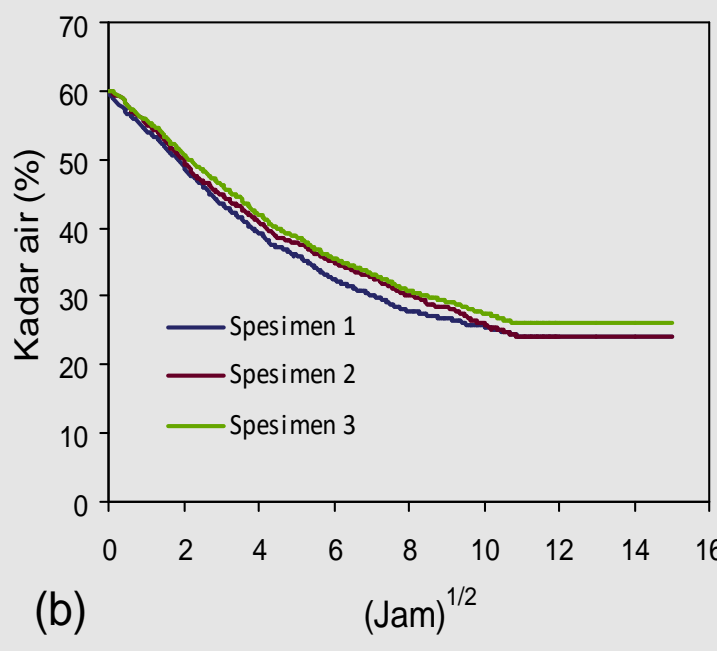

Gambar 4. Grafik kelembaban sesudah perendaman spesimen kayu jati.

Hasil absorbsi dan desorbsi air ditampilkan dalam bentuk kurva akar waktu vs kadar air seperti terlihat di Gambar 4. Dari gambar 4a terlihat bahwa air terserap cukup cepat di daerah linier tetapi kemudian air mulai terserap secara perlahan $\mathrm{Hal}$ ini ditunjukkan dengan penurunan gradien kurva secara perlahan sampai terjadi kesetimbangan. Kurva tersebut menyimpang dari hukum Fick, dimana segera setelah mencapai kesetimbangan penyerapan air lagi cenderung konstan. Kadar air kayu tertinggi dengan perendaman selama 5 hari mencapai $60 \%$. Dari daerah linier diperoleh konstanta difusi untuk absorbsi adalah $2,03 \times 10^{-3}$ $\mathrm{mm}^{2} /$ menit. 
Dari Gambar 4b terlihat bahwa proses desorbsi air berjalan lebih lambat darti proses absorbsi. Hal ini ditunjukkan dengan nilai konstanta difusi untuk desorpsi sebesar 5,58 $x \quad 10^{-4} \mathrm{~mm}^{2} / \mathrm{menit}$ Proses desorbsi cenderung mengikuti Hukum Fick. Desorpsi pada suhu sama dengan suhu absorbsi, air

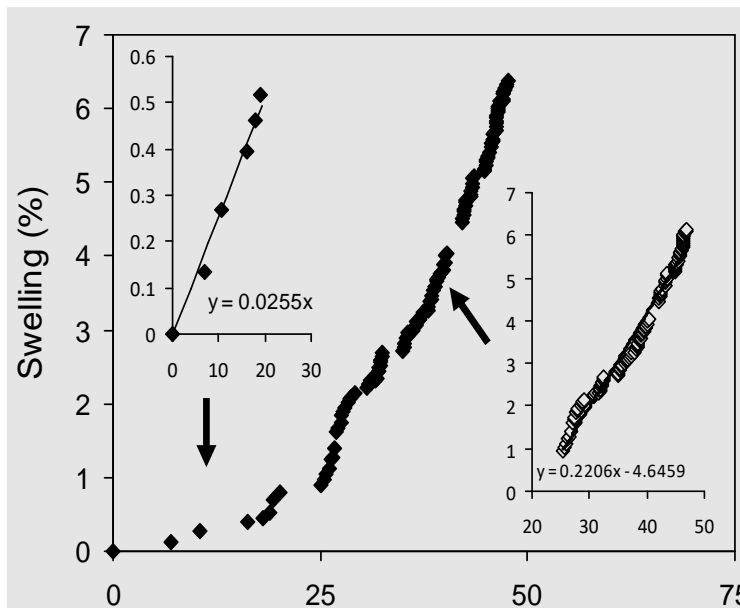

(a)

Kadar air rata-rata (\%) yang terdesorbsi tidak sama dengan air yang terabsorbsi. Air yang terdesorbsi sekitar 35\% sehingga terdapat sisa air sekitar $25 \%$. Untuk menghilangkan sisa air ini perlu suhu desorbsi yang lebih tinggi.

\section{Gambar 5. Grafik perbandingan kadar air dengan swelling rata-rata.}

\section{Swelling dan susutan}

Gambar 5 menunjukkan kurva swelling dan penyusutan rata-rata kayu akibat proses absorbsi dan desorbsi. Pada asborbsi (Gambar 5a) terlihat bahwa pada kadar air sebelum mencapai $25 \%$, terjadi laju swelling yang kecil $(0.023 \% / \%$ kadar air), ditunjukkan dengan kemiringan kurva yang rendah, tetapi setelah kadar air lebih dari 25\% hingga $48 \%$ terjadi laju swelling yang tinggi $(0,22 \% / \%$ kadar air), ditunjukkan dengan kemiringan kurva yang naik secara tajam. Ini disebabkan karena pada tahap awal penyerapan, air masuk ke dalam rongga kayu yang kosong sehingga tidak menyebabkan swelling yang tinggi (maksimum 1\%). Setelah rongga kayu terisi penuh maka akan mengakibatkan swelling kayu bertambah secara signifikan dengan semakin banyaknya kadar air dalam kayu hingga $7 \%$.

Pada desorbsi (Gambar 5b) terlihat susutan mempunyai pola yang sama seperti pada absorpsi, bahwa pada awalnya laju susutan lambat dari kadar air $60 \%$ sampai $34 \%(0.076 \% / \%$ kadar air), kemudian pada tahap akhir desorbsi, dari $34 \%$ sampai $25 \%$, lajunya meningkat sekitar $0,15 \% / \%$ kadar air. Hal ini mengindikasikan bahwa setelah proses absorbsi kemudian dilanjutkan desorbsi, air yang terdesorbsi mula-mula dari rongga-rongga kayu, sehingga air yang menyebabkan swelling tinggi, belum mempunyai kesempatan keluar. Air di dalam rongga-rongga kayu tidak menyebabkan swelling yang tinggi, sehingga ketika keluar mereka juga tidak menyebabkan susutan yang tinggi. Ketika air dalam struktur molekul kayu mempunyai kesempatan keluar, laju susutan meningkat. Walaupun ada batas yang jelas antara laju susutan rendah dan laju susutan tinggi, namun tidak diketahui secara pasti kapan air dalam struktur kayu mulai keluar karena susutan merupakan akumulasi dari air yang keluar dari ronggarongga kayu dan dari struktur kayu.

\section{Kekuatan sambungan kayu}

Gambar 6 menunjukkan kekuatan tarik kayu jati dengan berbagai kadar air di dalamnya dengan starndard deviasinya ditunjukkan dengan bar vertikal. Terlihat bahwa kekuatan tarik kayu menurun dengan meningkatnya kadar air. Pada kadar air 37\% dan $54 \%$, kekuatan tarik kayu turun masingmasing sekitar $7 \%$ dan $25 \%$. penurunan tersebut disebabkan oleh efek plastisisasi kayu yang disebabkan oleh air yang masuk ke struktur molekul kayu sehingga menyebabkan kayu mudah untuk dideformasi. Untuk hampir semua polimer dan komposit jika menyerap air, maka akan menyebabkan plastisisasi yang menuju ke penurunan sifat mekaniknya seperti kekuatan tarik dan kekakuan [11]. Kayu merupakan 
sebuah komposit yang tersusun oleh matrik lignin dan penguat selulosa. Matrik dan penguat tersebut termasuk bahan polimer efek plastisisasi juga terjadi pada kayu. Efek plastisisasi menjadi besar bila molekul masuk ke struktur molekul kayu sehingga saat mendekati jenuh kekuatan kayu mengalami penurunan yang semakin besar.

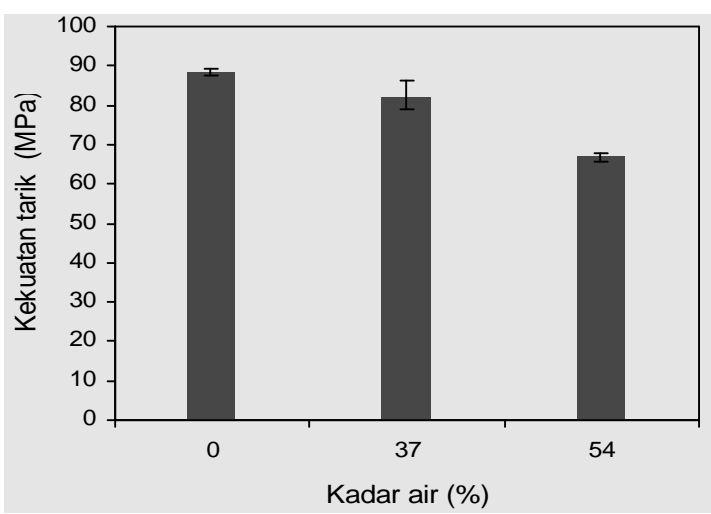

Gambar 6. Grafik perbandingan nilai kekuatan tarik kayu dengan kelembaban kayu.

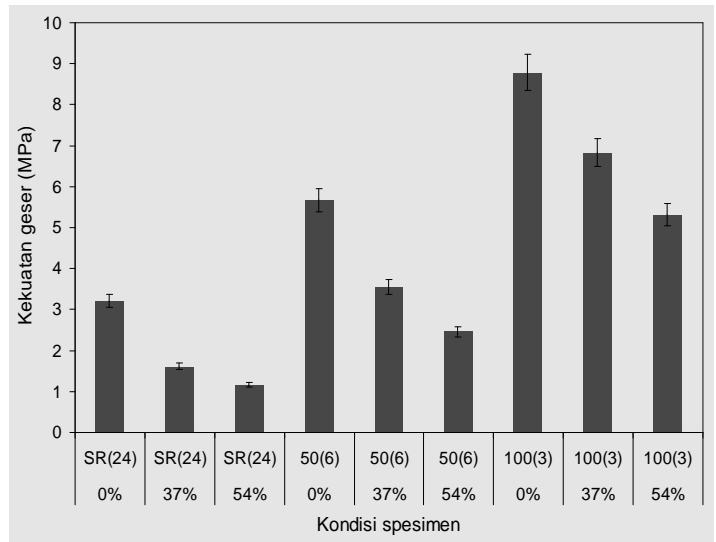

Gambar 7. Kekuatan geser perekat dengan lama waktu curing serta kelembaban specimen sebelum perekatan.

Gambar 7 menunjukkan kekuatan geser kayu pada berbagai kadar air awal kayu dan suhu curing. Bar vertikal menunjukkan standard deviasi. Semakin tinggi kadar air awal kayu, pada suhu curing yang sama kekuatan geser dari sambungan perekat semakin rendah. Tetapi penurunan kekuatan geser kayu tersebut berkurang bila suhu curingnya dinaikkan. Hal ini mungkin disebabkan karena adanya air pada permukaan kayu menghalangi proses perekatan antara epoxy dan kayu, sehingga semakin banyak kadar air proses perekatan semakin sulit. Lagi pula selama proses curing perekat, air dari dalam kayu dapat masuk ke perekat dan mempengaruhi proses curing. Proses desorpsi air dari kayu yang lambat memungkinkan proses tersebut terjadi. Air yang masuk ke perekat mempengaruhi reaksi curing antara resin dengan epoxy menyebabkan perekat tidak mampu untuk curing sempurna. Lebih jauh, bila perekat mengering dan air dari kayu mampu untuk berdifusi ke interface dan perekat, plastisisasi perekat akan terjadi dan menurunkan sifat mekanik perekat.

Bila dilihat dari kekuatan geser pada kadar air yang sama, kekuatan geser cenderung naik dengan meningkatnya suhu curing baik pada kayu kering, dengan kadar air 37\% dan 54\%. Pada kondisi kering, meningkatnya suhu curing jelas memperbaiki ikatan perekat dan kayu disamping, sifat mekanik perekat juga lebih baik karena curing terjadi lebih baik. Kondisi ini ditunjukkan dengan kekuatan geser yang paling tinggi dibanding bila kayu mengandung air. Namun demikian, pada kayu yang mengandung air meningkatnya suhu curing mampu mengurangi efek buruk dari air, bahkan pada suhu curing $100{ }^{\circ} \mathrm{C}$, kandungan air yang tinggi (54\%) pada kayu, menghasilkan kekuatan yang lebih tinggi dibanding curing pada suhu kamar dengan kayu kering. Curing dengan suhu tinggi mampu menghilangkan air secara cepat dari kayu yang menghalangi proses perekatan, dan juga mampu mengurangi air yang masuk ke interface dan perekat.

Pengaruh kombinasi air dan suhu curing jelas mempengaruhi kekuatan geser sambungan yang ditunjukkan dengan analisis statistik ANOVA dua arah. Dari dua variabel yang diteliti, ada interaksi antara kedua variabel tersebut dan pengaruh suhu curing lebih dominan dari kadar air.

\section{Mode Kegagalan sambungan}

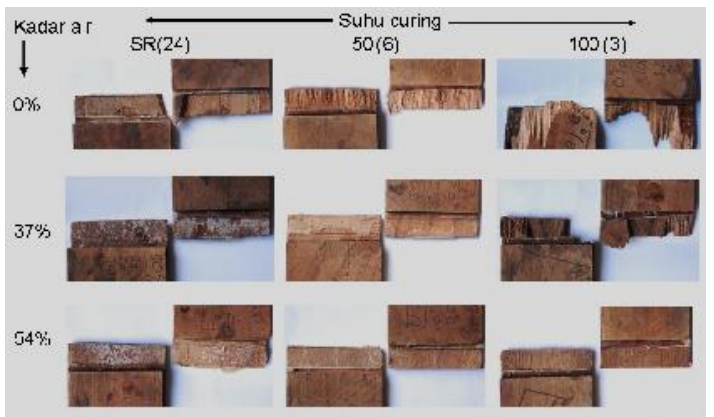

\section{Gambar 8. Gambar kegagalan/struktur} patahan spesimen uji geser.

Gambar 8 menunjukkan mode kegagalan spesimen sambungan pada berbagai kadar air dan suhu curing. Pada kondisi kayu kering $(0 \%)$ dengan suhu curing 
suhu kamar selama 24 jam, terjadi kegagalan interfacial dan sedikit pada kayu. Namun dengan meningkatnya suhu curing kegagalan mulai terjadi pada kayu, dibawah daerah overlap. Pada suhu curing $50{ }^{\circ} \mathrm{C}$ kegagalan ini bermula dari ujung sambungan yang kemudian merambat ke ujung sambungan yang lain. Tetapi pada suhu curing $100^{\circ} \mathrm{C}$, kegagalan terjadi pada kayu di luar daerah overlap, tetapi tetap bermula dari dekat daerah ujung overlap. Kegagalan yang terjadi pada kayu menunjukkan bahwa kekuatan geser daerah overlap lebih tinggi dari yang tertera pada Gambar 7. Pada komposit seperti kayu, kekuatan dalam arah tegak lurus serat (kekuatan tranversal) adalah jauh lebih lemah dibanding kekuatan searah serat, sehingga kegagalan pada kayu ini secara tidak langsung menunjukkan kekuatan tranversal kayu, walaupun pada ujung sambungan ini terjadi kondisi tegangan yang kompleks akibat pembebanan yang tidak kolinier pada sambungan.

Dengan adanya kandungan air pada kayu, sebagian besar kegagalan sambungan terjadi secara kohesif pada perekat, walaupun pada suhu curing tinggi $\left(100{ }^{\circ} \mathrm{C}\right)$ kegagalan terjadi pada kayu di bawah daerah overlap. Pada sambungan dengan kadar air $37 \%$ dan $54 \%$, curing pada suhu kamar, warna perekat yang gagal keputihan yang menunjukkan bahwa air mempengaruhi proses curing perekat, sehingga curing tidak terjadi dengan sempurna dan kegagalan terjadi secara kohesif pada perekat. Warna perekat tersebut menjadi lebih pucat dengan meningkatnya suhu curing ke $50{ }^{\circ} \mathrm{C}$. Lagi pula pada suhu curing $50^{\circ} \mathrm{C}$ kegagalan yang terjadi juga menjadi interfacial (pada kadar air $37 \%$ ) atau secara kohesif pada perekat tetapi dekat dengan interface (pada kadar air 54\%). Pada suhu curing $100{ }^{\circ} \mathrm{C}$, kadar air $37 \%$, sambungan mengalami kegagalan pada kayu di bawah overlap, sedang pada kadar air $54 \%$, kegagalan terjadi sangat tipis pada kayu di bawah overlap.

\section{KESIMPULAN}

Proses penelitian pada penyerapan air pada kayu, pengaruh kadar air awal (kering, $37 \%$ an $54 \%$ ) pada kayu dan suhu curing perekat (suhu kamar, $50{ }^{\circ} \mathrm{C}$ dan $100{ }^{\circ} \mathrm{C}$ ) pada kekuatan sambungan kayu jati secara perekatan telah dilakukan dan diperoleh beberapa kesimpulan sebagai berikut:

1. Proses absorbsi air pada kayu jati menyimpang dari hukum Fick, tetapi proses desorbsi lebih cenderung mengikuti hukum Fick. Laju absorbsi air lebih cepat daripada laju desorbsi air dari kayu jati. Pada suhu desorbsi yang sama dengan suhu absorbsi (suhu kamar), masih ada air yang tertinggal dalam kayu kira-kira $25 \%$ dari $60 \%$ kadar air terserap.

2. Proses swelling pada kayu arah transversal mula-mula lambat hingga kadar air mencapai sekitar 20\% karena air mengisi rongga-rongga kosong pada kayu dan kemudian semakin cepat setelah kadar air tersebut. Demikan juga proses desorbsi air dari kayu, laju desorbsi mulamula juga lambat hingga kadar air turun dari $60 \%$ ke $34 \%$ dan kemudian meningkat di bawah kadar tersebut.

3. Kekuatan geser sambungan semakin menurun dengan meningkatnya kadar air awal dalam kayu dan semakin tinggi suhu curing mampu meningkatkan kekuatan sambungan. Pengaruh suhu curing lebih dominan daripada pengaruh kadar air awal dalam kayu dan mampu mengurangi pengaruh buruk kadar air pada kekuatan sambungan. Suhu curing $100{ }^{\circ} \mathrm{C}$ mampu menghasilkan kekuatan geser sambungan paling tinggi dari suhu curing suhu kamar dan $50{ }^{\circ} \mathrm{C}$ pada semua kadar air awal kayu yang dipelajari.

4. Mode kegagalan pada kondisi kayu kering cenderung kohesif di dalam kayu jati, terutama pada suhu curing tinggi $\left(50^{\circ} \mathrm{C}\right.$ dan $100{ }^{\circ} \mathrm{C}$ ), tetapi pada kondisi kayu basah (37\% dan 54\%) kegagalan cenderung kohesif di dalam perekat pada suhu kamar, kemudian ke interfacial (kadar air 37\%) atau kohesif pada perekat di dekat interface (kadar air 54\%) pada suhu curing $50{ }^{\circ} \mathrm{C}$. Pada curing $100{ }^{\circ} \mathrm{C}$, kegagalan terjadi pada kayu secara transversal untuk semua kadar air yang dipelajari.

\section{DAFTAR PUSTAKA}

[1] Vick, CB., Adhesive Bonding of Wood Materials, Chapter 10, in Wood handbook-Wood as an engineering material. Gen. Tech. Rep. FPL-GTR113. Madison, WI: U.S. Department of Agriculture, Forest Service, Forest Products Laboratory; 1999.

[2] KI usler O, Clauß S, Lübke L, Trachsel $\mathrm{J}$, Niemz $\mathrm{P}$, Influence of moisture on stress-strain behaviour of adhesives used for structural bonding of wood, International Journal of Adhesion \& Adhesives 44 (2013) 57-65.

[3] Frihart, $C R$. Wood Adhesion and Adhesives, Chapter 9, in Handbook of wood chemistry and wood composites 
edited by Roger M. Rowell., Florida: CRC Press; 2005.

[4] Davalos, J. F., Qiao, P. Z., and Trimble, B. S., "Fiber-Reinforced Composite and Wood Bonded Interfaces: Part 1. Durability and Shear Strength," Journal of Composites Technology \& Research, JCTRER, Vol. 22, No. 4 (2000) 224231.

[5] Dinwoodie JM.. Timber: its nature and behaviour 2nd ed London: Taylor \& Francis; 2000.

[6] Sugiman, Pengaruh Suhu Curing Terhadap Kekuatan Lelah Sambungan Perekat Baja Karbon Dengan Perekat Steel - Filled Epoxy, Journal Rekayasa, Vol. 6, No.1 (2005) 68-74.
[7] Sugiman and Masri, Pengaruh Kelembaban Adherend pada Durabilitas Perbaikan Komposit, Jurnal Teknik Mesin Vol. 8, No.2 (2006) 49-56.

[8]. Crank, J. The mathematic of diffusion. 2nd edition. London: Oxford University Press; 1975.

[9] Standard Nasional Indonesia, Metode Pengujian Kuat Tarik Kayu Di Laboratorium SNI 03-3399-1994, Badan Standardisasi Nasional, Jakarta; 1999.

[10] Ozcan, S., Ozcifci, A., Hiziroglu, S., Toker, H., Effects of Heat Treatment and Surface Roughness on Bonding Strength, Contruction and Building Material 33 (2012) 7-13.

[11] Kinloch, A.J., Adhesion and Adhesives: science and technology, London: Chapman \& Hall; 1987. 